\title{
The Geological Survey and Museum
}

$\mathrm{T}$ HE new building for the Geological Survey and Museum which has been erected on the west side of Exhibition Road, South Kensington, London, S.W.7, stands in a middle position between the Victoria and Albert Museum, the Science Museum and the British Museum (Natural History). The site which it occupies is part of the ground acquired by the Royal Commissioners of the 1851 Exhibition, and was chosen for this purpose by stone; but the rest of the building is of brick with stone sills and courses. The shape is a simple rectangle 312 feet long by 100 feet wide and 95 feet high. The Museum occupies the front part of the building while at the rear are the Survey offices, laboratories and library.

Large, metal-framed windows occupy almost the whole of the sides of the building, and in order to secure as much light as possible the amount

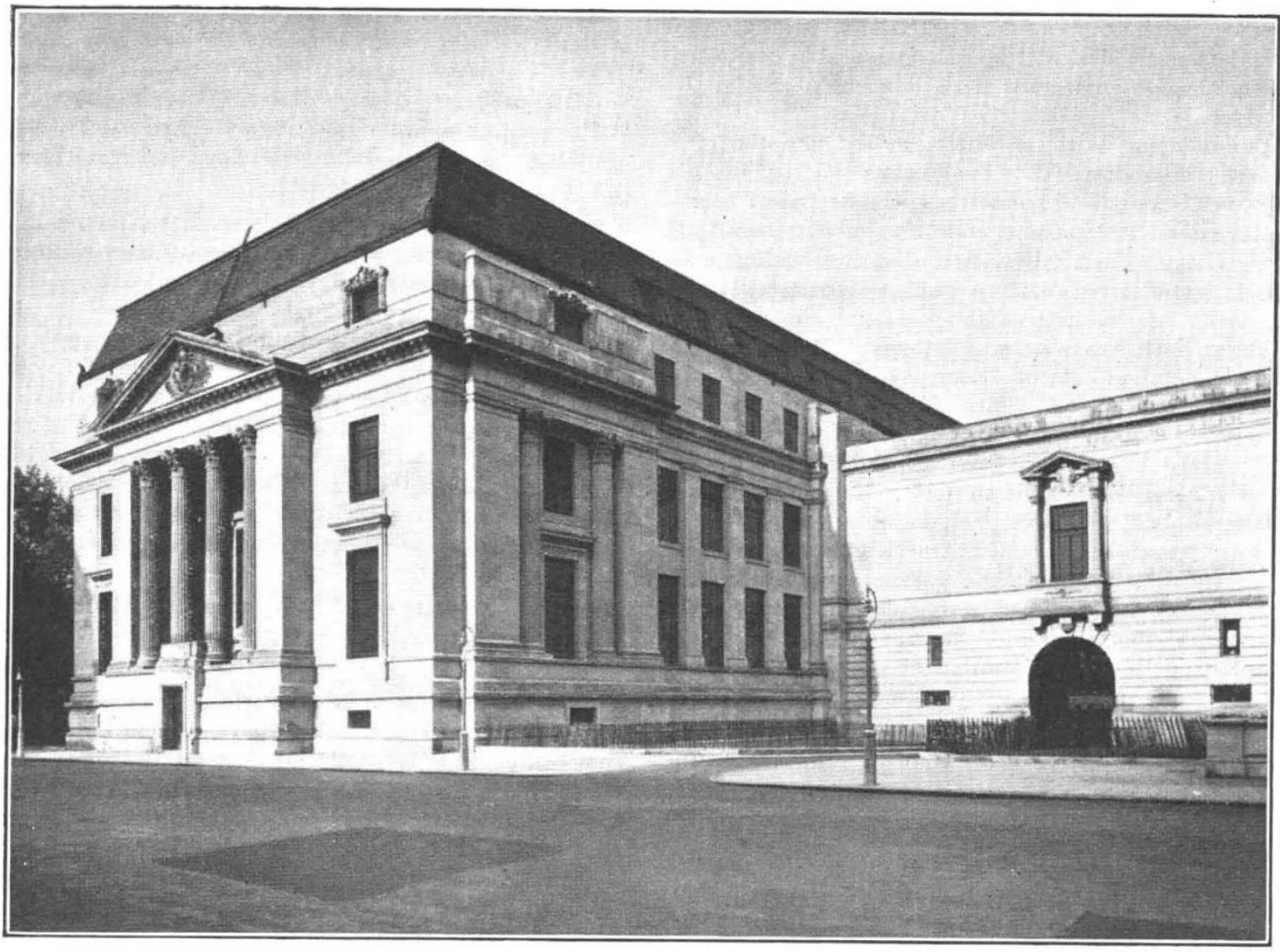

Fig. 1. Geologieal Survey and Museum, South Kensington.

the Bell Committee (1912). The new Museum (Fig. 1) is linked to the Science Museum by a series of corridors over an arched gateway; at some future time, the Natural History Museum may be extended to the east, and the new buildings will probably join up with the Geological Survey and Museum on its south side.

The building was designed by Mr. John H. Markham, of H.M. Office of Works. Its eastern front, facing Exhibition Road, is of classical design, with a Corinthian colonnade, and has been described by competent judges as one of the most successful recent classical buildings in London. The front archway and part of the north side is of Portland of dead wall has been severely cut down. The result is that the interior is very well lighted. The general arrangement is that of a central court or well, forty feet wide, lighted from above by a glazed, arched roof, and side galleries, thirty feet wide, lighted by the windows in the walls. The exhibition space comprises a main floor and two galleries, and there are large staircases at each end of the Museum. The galleries are supported on rectangular steel pillars, and the whole building is steel framed, with concrete floors; it is as nearly fireproof as possible. In the Museum there are no partitions, separating the interior into rooms, but the whole structure is open. The 


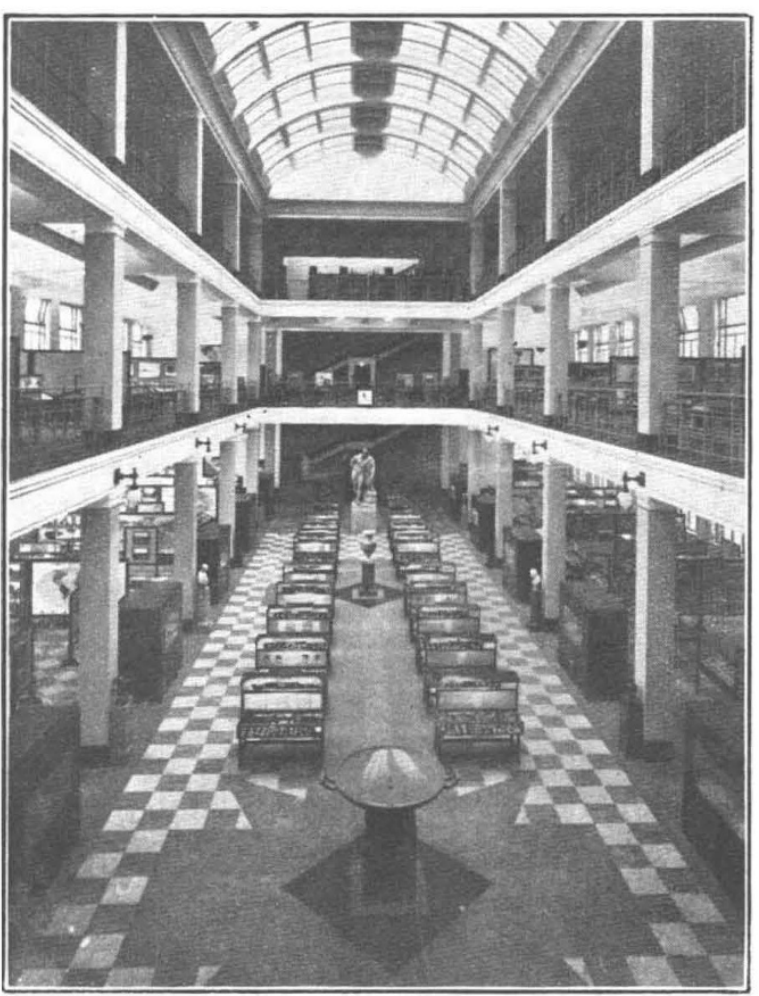

Fit. 2. General view of interior, showing the central court and two exhibition galleries.

entrance hall and eastern staircase are lined with polished marbles, but in the rest of the building there has been no attempt at decoration, and the architect has relied principally on proportion and symmetry to obtain his effects.

The transfer of the collections from the old interesting the general public who have no special knowledge of the science. A very fine display of gems and semi-precious stones is placed in the centre court. To avoid the disturbing effect of reflections from the roof, the glazed cases have curved tops: they are also provided with artificial illumination. Such minerals as diamond, ruby, sapphire, emerald, topaz, zircon, peridot and lapis lazuli are shown on one side, and on the other onyx, agate, jasper, opal, chalcedony, labradorite and adularia.

The side spaces under the galleries are divided up into bays by means of vertical screens about seven feet high. These screens are covered with photographs showing scenes of geological interest. Each bay illustrates a subject, such as glaciers, earthquakes, volcanoes, marine deposits, river action, rock structure, weathering, the action of plants or the origin of coal. In the table cases a very complete series of specimens, fully labelled, provides examples, mostly of British origin. Each table case also has a medial screen with coloured sketch maps, sections and diagrams. The principle followed has been not to show too many specimens, but to see that all are as typical as possible and to explain their meaning fully and clearly. On this floor also there is a group of dioramas representing picturesque scenes of geological significance, such as the Needles and Alum Bay (Isle of Wight), Edinburgh as seen from Braid Hills, the Avon Gorge (Bristol), Lulworth Cove, Cheddar Cave and Vesuvius (in eruption). It is intended that on this floor the exhibits will interest and attract visitors who have no special knowledge of geology.

In the first gallery, the object aimed at is to Museum in Jermyn Street was completed by the end of October 1934, and the old Museum is now being demolished. The Geological Survey and Offices have been occupied, and the library has been open to the public since November. Considerable progress has been made in the work of arranging the exhibits, and when the new Museum is opened on July 3 by H.R.H. The Duke of York, it will be found that all the floors are covered with displays, which are practically entirely new and totally different from those which were shown in the Jermyn Street Museum.

The main floor (Fig. 2) has been devoted to an exhibition of the introductory principles of geology with the object of

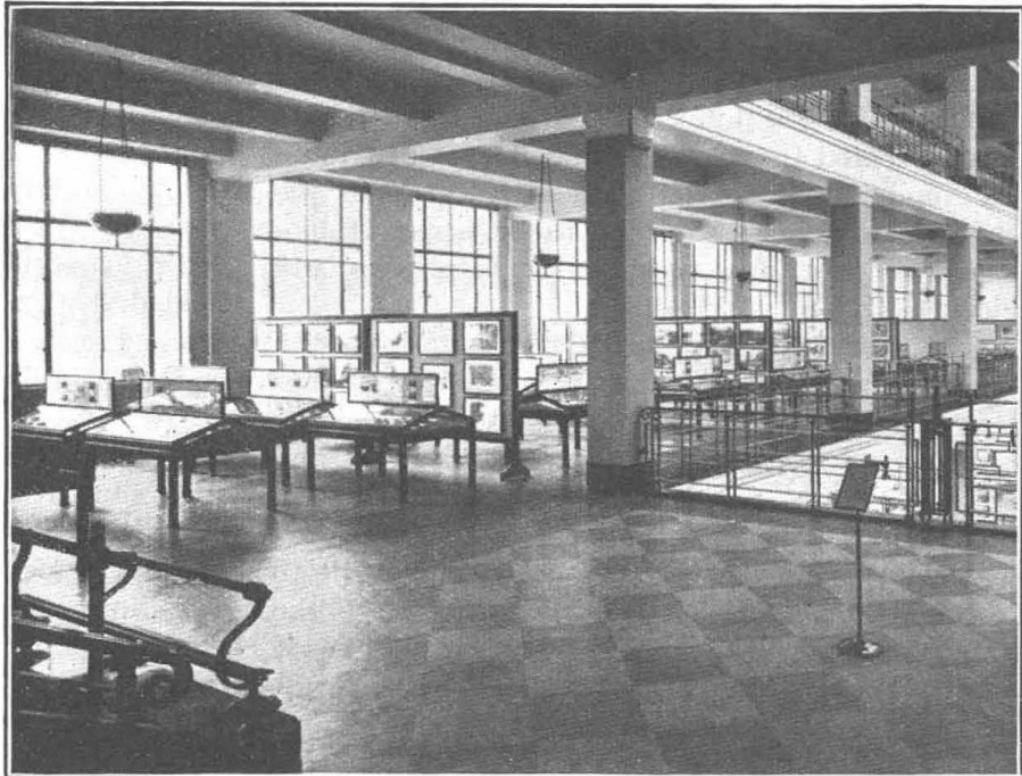

FIG. 3. East end of first gallery, showing division by sereens carrying photographs. 
show the geology of Great Britain. For this purpose the country has been divided into areas or regions that have a definite geological and also geographical identity. Examples are London and Thames Valley, the Weald of Kent, Devon and Cornwall, South Wales, North Wales, Hampshire Basin, Northern Highlands of Scotland, Central Valley of Scotland. Each region is fully illustrated with maps, photographs, sections, rocks, fossils and minerals. A special descriptive handbook of each province is being written by an expert geologist who knows the district thoroughly.

In the second gallery, the exhibits are intended to explain the origin of the prinçipal metals and the economic application of geology. In the table cases are selected specimens of the ores of iron, lead, zinc, copper, manganese, etc., and also a full exposition of useful non-metallic minerals such as talc, gypsum, china clay, rock salt. In special cases there is a large series of British building stones, and such subjects as roadstones, slates, cements, brick clays and asphalts will also have space assigned to them.
One of the most important features of this Museum is the accommodation provided for research material and for investigators who wish to work on the Survey's collections. In the top of the Museum there is a third gallery (not visible from the main floor) with about 16,000 feet of floor space, excellently lighted. This is to be reserved entirely for cabinets containing those specimens of minerals, rocks and fossils that are of special interest and importance, and likely to be consulted by scientific experts. There is also in the basement of the Museum a large store containing drawers filled with material of less importance which requires to be preserved not for its inherent interest but rather as a record on which statements in the Survey memoirs are founded.

The new Museum and Offices are nearly three times as large as the building formerly occupied. The cost of the building was approximately $£ 220,000$. The old Museum in Jermyn Street has been let on a building lease by the Commissioners of Crown Lands at a yearly rental of $£ 11,000$.

\section{Clinical Science within the University}

$\mathrm{I}^{\mathrm{N}}$ $\mathrm{N}$ the Huxley Lecture delivered at the University of Birmingham on March 14 and published in the British Medical Journal of March 30, Sir Thomas Lewis made a strong appeal on behalf of the recognition of clinical science, which may be regarded as an answer to the presidential address of Sir Frederick Gowland Hopkins on "Clinical Medicine and Science", a survey of which appeared in NatuRE of December 8, 1934 (p. 867). In his address Sir Frederick expressed his conviction that the scope for really controlled experiments applicable to the human body was limited, and he deprecated the growing tendency to distribute the funds provided for medical research in the endowment of the clinic at the expense of biological science, and particularly biophysics and biochemistry.

Sir Thomas Lewis started by quoting with approval the declaration made by Sir James Paget sixty-five years ago, that "clinical sejence has as good a claim to the name and rights and self-subsistence as any other department of biology" ; but he used the term "clinical science" in a wider sense than Paget, who confined it to researches on living man, by defining it as "the branch of knowledge that centres upon diseased human beings, but which also includes relevant parts of the allied sciences". The field of clinical science therefore should include physiology, morbid anatomy and experimental medicine.
Sir Thomas emphasised the point that clinical science is not identical with clinical medicine and clinical surgery, and drew a distinction between the science and art of medicine ; but he maintains that a university must possess a strong scientific department inspired by direct clinical interests.

As regards experimental work, Sir Thomas declared that every remedy employed to-day is the result of direct experiment on man, as is best exemplified by vaccination, antiseptic surgery and general anæsthesia. Only safe and beneficial experiments are justifiable, and no experiments should be carried out except with the patient's consent. In Sir Thomas's opinion, too many experiments have been and are still being performed; a reduction in their number, and their conduct on a stricter, safer and more productive basis are desirable.

The first requirement of a university department of elinical science is an out-patient department and an in-patient service sufficient to supply ample material for research and teaching, the size of the departments to be decided partly by local conditions and partly by the activities of the professor and his assistants. While admitting that clinical science is essentially a laboratory science, Sir Thomas does not think that the laboratory should be a place reserved for animals. On the contrary, he maintained that laboratories for the 